\title{
FIRE RISK MAP FOR THE SERRA DE SÃO DOMINGOS MUNICIPAL PARK, POÇOS DE CALDAS, MG
}

\author{
Henrique Nery Cipriani ${ }^{1}$, José Aldo Alves Pereira ${ }^{2}$, Rossi Allan Silva ${ }^{3}$, \\ Sávio Gouvêa de Freitas ${ }^{4}$, Luciano Teixeira de Oliveira ${ }^{5}$
}

(received: December 3, 2009; accepted: November 30, 2010)

\begin{abstract}
This study constructed a fire risk map for the Serra de São Domingos Municipal Park (SSDMP), southern Minas Gerais Sate, Brazil, which harbors Atlantic Forest remnants and endangered species. Geo-processing techniques were used for producing a preliminary risk map for altimetry (a), land slope (e), slope orientation (d), land-use/cover (u) and influence of roads and buildings (i). After, the risk maps were overlaid to produce a structural fire index (SFI)-based risk map for the Park. The SFI was calculated by using the formula SFI $=0,35 \mathrm{i}+0,30 \mathrm{u}+0,15 \mathrm{~d}+0,10 \mathrm{a}+0,10 \mathrm{e}$. The risks classes were classified as low $(0.0-0.9)$, moderate (1.01.9), high (2.0-2.9), very high (3.0-3.9) and extreme (4.0-5.0). All data were processed with $2.5 \mathrm{~m}$ base spatial resolution by using the ArcView GIS. According to the SFI calculated, the SSMP area can be divided into the following fire risk zones: Low (0.93\%), Moderate (61.77\%), High (31.32\%), Very High (4.79\%) and Extreme (1.19\%). The main risk factor is due to the influence of roads and buildings and most fires start due to anthropogenic causes. The low and moderate risk classes comprehend most of the rainforest area. Clearings and grasslands fit mainly the High risk class. The most vulnerable area of SSDMP was the Northern area bordering pasture, crops and eucalypt fields. The SFI map can be a valuable tool for elaborating a fire prevention plan in a small conservation unit when few climate and fire occurrence data are available.
\end{abstract}

Key words: Atlantic Forest, conservation unit, fire prevention, on-the-screen visual image interpretation.

\section{ZONEAMENTO DE RISCO DE INCÊNDIOS PARA O PARQUE MUNICIPAL DA SERRA DE SÃO DOMINGOS, POÇOS DE CALDAS, MG}

\begin{abstract}
RESUMO: Objetivou-se, com este estudo, produzir um mapa de risco de incêndio para o Parque Municipal da Serra de São Domingos (PMSSD), sul de Minas Gerais, Brasil, que abriga remanescentes de Mata Atlântica e espécies ameaçadas de extinção. Técnicas de Geoprocessamento foram utilizadas para produzir mapas de risco preliminares para altimetria (a), declividade do terreno (e), uso e cobertura do solo $(u)$, orientação de encosta (d) e influência de estradas e construções (i). Os mapas foram integrados, gerando um mapa baseado no índice estrutural de risco de incêndio (SFI) calculado pela fórmula SFI $=0,35 i+0,30 u+0,15 d+0,10 a+0,10$ e As classes de risco foram definidas como Baixo (0,0-0,9), Moderado (1,0-1,9), Alto (2,0-2,9), Muito Alto (3,0-3,9) e Extremo (4,0-5,0). Os dados foram trabalhados com resolução espacial de 2,5 m utilizando-se o ArcView SIG. A área do PMSSD pode ser distribuída nas seguintes classes: Baixo (0,93\%), Moderado (61,77\%), Alto (31,32\%), Muito Alto (4,79\%) e Extremo (1,19\%). O principal fator de risco é a influência de estradas. As classes de risco Baixo e Moderado abrangem a maior parte da cobertura florestal. Clareiras e pastagens ocupam principalmente a classe de risco Alto. A área mais vulnerável do SSDMP é a sua fronteira com pastagens e plantios de café e eucalipto ao norte. O mapa baseado no SFI pode ser um valioso subsídio para a elaboração do plano de prevenção de incêndio de pequenas unidades de conservação com poucos dados relativos ao clima e ao histórico de ocorrência de incêndio disponíveis.
\end{abstract}

Palavras-chave: Classificação visual criteriosa, Mata Atlântica, prevenção de incêndio, unidade de conservação.

\section{INTRODUCTION}

Except for some tropical rainy regions, fire is the main source of damage to forests throughout the world, affecting soil, vegetation, wildlife and the environment, having an important share in greenhouse gas emissions (SANT'ANNA et al., 2001). In addition, many forests, such as those of national, state or municipal parks, have a recreation role, presenting a pleasant landscape aspect. Fires can change this scenario, making the forest, at least temporarily, unfit for recreational activities (SOARES; BATISTA, 2007), rendering it less attractive and reducing, therefore, its tourist potential.

\footnotetext{
${ }^{1}$ Forest Engineer, Masters student in Soil and Plant Nutrition - Universidade Federal de Viçosa/UFV - Av. Peter Henry Holfs, s/n - Campus Universitário - Viçosa, MG, Brasil - 36570-000 - hncipriani@hotmail.com

${ }^{2}$ Forest Engineer, Lecturer D.Sc. in Ecology - Departamento de Ciências Florestais - Universidade Federal de Lavras/UFLA-Cx.P. 3037 - 37200-000 Lavras, MG, Brasil - j.aldo@dcf.ufla.br

${ }^{3}$ Forest Engineer, Masters student in Forest Engineering - Departamento de Ciências Florestais - Universidade Federal de Lavras/UFLA - Cx.P. 3037 37200-000 - Lavras, MG, Brasil - rossiallan@gmail.com

${ }^{4}$ Forest Engineer - Instituto Estadual de Florestas/IEF - Rua Misericórdia, 798, Centro - Oliveira, MG, Brasil - 35540-000 - saviogouvea@hotmail.com ${ }^{5}$ Forest Engineer, Doctoral student in Forest Engineering - Departamento de Ciências Florestais - Universidade Federal de Lavras/UFLA - Cx.P. 3037 -37200-000 - Lavras, MG, Brasil - oliveiralt@hotmail.com
} 
For a Conservation Unit (CU) such as the Serra de São Domingos Municipal Park (SSDMP), which besides receiving a large number of tourists harbors remnants of endangered species of Atlantic Rainforest, it is essential that there be mechanisms to, effectively, control forest fires, ensuring its integrity for the welfare of animals, plants and people who make use of the facility in various ways.

Prevention must be part of any fire control strategy because it does not matter, how good a firefighting scheme might be, it is always better to prevent the fire outbreak. Nevertheless, in the case of a fire outbreak, if a good prevention plan is available for implementation, it will allow a faster and more efficient action.

The geographic information system (GIS) and remote sensing are useful tools for use in prevention plans, since they allow the production of fire risk maps that indicate regions of the UC prone to fire outbreaks and which are the main factors responsible for that vulnerability (CHUVIECO et al., 2010; NÚÑEZ-REGUEIRA et al., 2000). Many methodologies have been used in the production of fire prevention maps, differing mainly in the variables that are used to calculate the fire risk index (CHUVIECO et al., 2010; FERRAZ; VETTORAZZI, 1998; HERNANDEZ-LEAL et al., 2006; NÚÑEZ-REGUEIRA et al., 2000; OLIVEIRA et al., 2004; RIBEIRO et al., 2008).

According to its time scale, a fire risk index can be classified as structural, dynamic or integrated (JRC, 2001, apud FREIRE et al., 2002). The first one is composed only of factors that remain unaltered for a relatively long time, such as topography and land-use; the second one is calculated by using parameters that are constantly changing (weather conditions, litter moisture etc.); and the third type use both types of data. Although integrated fire indexes are considered the most reliable, they require more data to be calculated (CHUVIECO et al., 2010). Nonetheless, structural fire indexes have been used successfully in the production of many maps with few adaptations (DALCUMUNE; SANTOS, 2005; FREIRE et al., 2002; RIBEIRO et al., 2008).

In the case of the Serra de São Domingos Municipal Park, where there is lack of climatologic and fire history data, the adoption of a simpler methodology based on static physical variables might prove useful for a preliminary approach on the fire risk assessment for the CU. In this regard, the objective of this study was to produce a fire risk map for the SSDMP to subsidize its fire prevention plan.

Cerne, Lavras, v. 17, n. 1, p. 77-83, jan./mar. 2011

\section{MATERIAL AND METHODS}

\subsection{Location}

The Serra de São Domingos Municipal Park is located in the northern region of Poços de Caldas city, southern Minas Gerais Sate, Brazil, coordinates $21^{\circ} 46^{\prime} 25^{\prime \prime} \mathrm{S}$ and $46^{\circ} 34^{\prime} 10^{\prime \prime} \mathrm{W}$ (Christ statue). It covers an area of 367.60 ha, $74.36 \%$ being occupied by rainforest, $13.26 \%$ by grassland vegetation (the highest part of the Park), $6.09 \%$ by pasture, $1.04 \%$ by exposed soil, $1.24 \%$ by crops (mainly coffee), $0.46 \%$ by urbanized areas and $0.23 \%$ by inactive bauxite mines. There are no water bodies of significant size in the Park, but several springs can be found scattered around the rainforest area.

Urbanized areas comprehend the Park roads and touristic spots, which are the Christ Redeemer statue, the astronomic observatory (currently disabled), the aquarium, the cable car and the free-flight ramp, all located around the hilltop. There are also two touristic spots located at the lowest part of the Park hill, Recanto Japonês (a Japanesestyle garden) and Fonte dos Amores ("love spring”).

The land slope classes found in the Park are varied, with a predominance of the mountainous to wavy relief (Table 1). The flat lands are concentrated on the highest part of the Park. Only two types of soil are found within the Park: Red-Yelloow Podzolic, the most common, and Cambisol (SOUZA et al., 2007).

Table 1 - Land slope at Serra de São Domingos Municipal Park, Minas Gerais State, Brazil.

Tabela 1 - Declividade do terreno no Parque Municipal da Serra de São Domingos, Minas Gerias, Brasil.

\begin{tabular}{lcc}
\hline Slope & Area (ha) & Area (\%) \\
\hline $0-10^{\circ}$ & 25.44 & 6.92 \\
$10-20^{\circ}$ & 101.72 & 27.67 \\
$20-30^{\circ}$ & 161.52 & 43.94 \\
$30-45^{\circ}$ & 73.73 & 20.06 \\
$45-90^{\circ}$ & 5.2 & 1.41 \\
Total & 367.60 & 100.00 \\
\hline
\end{tabular}

In comparison to the surrounding city, the Park is located in areas of higher altitudes, approximately $1,200 \mathrm{~m}$ (Table 2). It is possible that precipitation and temperature data for the CU differ from the rest of the municipality, since altitude and topography may significantly influence the climate of the region (FERNANDES et al., 2003). 
Table 2 - Elevation at Serra de São Domingos Municipal Park, Minas Gerais State, Brazil.

Tabela 2 - Elevação no Parque Municipal da Serra de São Domingos, Minas Gerais, Brasil.

\begin{tabular}{lcc}
\hline Elevation $(\mathrm{m})$ & Área (ha) & Área (\%) \\
\hline $1200-1300$ & 40.75 & 11.09 \\
$1300-1400$ & 79.59 & 21.65 \\
$1400-1500$ & 116.77 & 31.77 \\
$1500-1600$ & 117.34 & 31.92 \\
$1600-1640$ & 13.15 & 3.58 \\
Total & 367.60 & 100.00 \\
\hline
\end{tabular}

Poços de Caldas climate is classified as Cwb type according to the Köppen classification (hot temperate with rains in summer). Considering the 1931-1960 climate normal, Poços de Caldas rainy season runs from September to March, with an average total of 1,478.7 $\mathrm{mm}$ for the period. The total average annual precipitation is $1,695.5 \mathrm{~mm}$. The average temperatures of the coldest (June) and hottest (February) months are $14.3^{\circ} \mathrm{C}$ and $20.5^{\circ} \mathrm{C}$, respectively.

Not only does the Park receive a large number of tourists annually, it also preserves a valuable Atlantic Forest fragment. Nineteen threatened plant species have already been found in floristic studies made in the Park, including critically endangered species (Euterpe edulis and Persea rufotomentosa). Researches on the fauna are currently in progress, but a vulnerable monkey group (Cebus sp.) and some endemic frog species are known to reside in the Park.

\subsection{Methods}

Preliminary risk maps were produced for each variable used to compose the final risk map: road system and buildings, altitude, land slope, slope orientation and land-use and cover. The land-use/cover map was produced from a SPOT V satellite image (date: 09-28-2006; spatial resolution: $2.5 \mathrm{~m}$ ) and an aerophotogrammetric survey (year 1997; spatial resolution: $0.6 \mathrm{~m}$ ). Aiming at maximizing the land-use and cover map precision, a systematic onthe-screen visual image interpretation approach was used to delineate the land-use/cover classes after the automatic classification. The other maps were made from digital files with planialtimetric data provided by the Poços de Caldas City Hall. All data were processed using the ArcView GIS with the Spatial Analyst extension, with $2.5 \mathrm{~m}$ base work spatial resolution, Datum SAD 69 and UTM-Fuse 23.
Each variable was categorized into classes and each of these classes received a coefficient value that represents its risk for the occurrence or spreading of fire in comparison to the other classes within the same variable. The coefficients ranged from one (low risk) to five (extreme risk), as used by Oliveira et al. (2004).

The altimetric variation of the Park was divided into two classes, as shown in Table 3. The higher the altitude, the lower the risk, since higher altitudes indicate less oxygen concentration and lower temperatures, which hinder the spreading of fire (SOARES; BATISTA, 2007).

Table 3 - Fire risk and coefficients due to the elevation at Serra de São Domingos Municipal Park, Minas Gerais State, Brazil.

Tabela 3 - Risco de incêndio e coeficientes devido à elevação no Parque Municipal da Serra de São Domingos, Minas Gerais, Brasil.

\begin{tabular}{lcc}
\hline Altitude & Risk & Coefficient \\
\hline Above $1400 \mathrm{~m}$ & Low & 1 \\
$1400 \mathrm{~m}$ and below & Moderate & 2 \\
\hline
\end{tabular}

Source: Adapted from Salas and Chuvieco (1994).

The land slope was divided into five classes in which the higher the declivity, the higher the coefficient (Table 4). Fire tends to spread out more intensely on sloping grounds due to the convection of heat to the combustible material located on the upper part. This causes the material to dry faster and burn in a more violent way (SOARES; BATISTA, 2007). Rugged topography also affects combat operations because it hampers the movement of vehicles and people.

Table 4 - Fire risk and coefficients due to the land slope and orientation at Serra de São Domingos Municipal Park, Minas Gerais State, Brazil.

Tabela 4-Risco de incêndio e coeficientes devido à declividade e orientação do terreno no Parque Municipal da Serra de São Domingos, Minas Gerais, Brasil.

\begin{tabular}{lccc}
\hline Slope & Orientation & Risk & Coefficient \\
\hline Until $14.9^{\circ}$ & South & Low & 1 \\
$15.0-24.9^{\circ}$ & East & Moderate & 2 \\
$25.0-34.9^{\circ}$ & Plain & High & 3 \\
$35.0-44.9^{\circ}$ & West & Very high & 4 \\
$45.0^{\circ}$ and above & North & Extreme & 5 \\
\hline
\end{tabular}

Source: Adapted from Ferraz and Vetorrazzi (1998) and Soares (1985).

Cerne, Lavras, v. 17, n. 1, p. 77-83, jan./mar. 2011 
The slope orientation influences on the fire risk inasmuch as it is related to the incidence of sunlight on the surface. The more direct the light incidence is, the higher the temperature and the lower the relative humidity. This causes the combustible material to dry faster and favors the fire spreading (SOARES; BATISTA, 2007). Table 4 shows the coefficient assigned to each sun exposure condition.

Regarding the influence of urban areas and roads, the Park was divided into two classes (Table 5): one considered under the influence of the road system and buildings and another class considered to be beyond the influence of roads and buildings. The first class represents the entire Park area within $15 \mathrm{~m}$ of distance from any road or building. The remaining areas were included in the second class. Nine land-use/cover classes were identified at the SSDMP, which were grouped into four risk classes (Table 6).

Table 5 - Fire risk and road and building influence coefficients at Serra de São Domingos Municipal Park, Minas Gerais State, Brazil.

Tabela 5 - Risco de incêndio e coeficientes devido à influência de estradas e edificações no Parque Municipal da Serra de São Domingos, Minas Gerais, Brasil.

\begin{tabular}{lcc}
\hline $\begin{array}{l}\text { Influence of road system } \\
\text { and buildings }\end{array}$ & Risk & Coefficient \\
\hline Beyond influence & Low & 1 \\
Under influence & Extreme & 5 \\
\hline
\end{tabular}

Source: Adapted from Salas and Chuvieco (1994).

Table 6 - Fire risk and coefficients due to land use at Serra de São Domingos Municipal Park, Minas Gerais State, Brazil.

Tabela 6 - Risco de incêndio e coeficientes devido ao uso do solo no Parque Municipal da Serra de São Domingos, Minas Gerais, Brasil.

\begin{tabular}{lcc}
\hline Land use & Risk & Coefficient \\
\hline $\begin{array}{l}\text { Water, buildings, rainforest } \\
\text { and exposed soil }\end{array}$ & Low & 1 \\
Agriculture and mines & Moderate & 2 \\
Afforestation & Very high & 4 \\
Pasture and grassland & Extreme & 5 \\
\hline
\end{tabular}

Source: Adapted from Oliveira et al. (2004).

Cerne, Lavras, v. 17, n. 1, p. 77-83, jan./mar. 2011
The integration of the preliminary maps was conducted with the aid of a balance model to which importance degrees (weight) were assigned to each variable, based on the analysis of the Park fire occurrence history (Table 7). The analysis indicated that the influence of the road system and buildings are the most relevant item composing the fire risk index, since most of the occurrences took place at or near tourist spots.

Table 7 - Number of fire occurrences for the years 2005, 2006 and 2007 at the Serra de São Domingos Municipal Park (Minas Gerais State, Brazil), and its surroundings.

Tabela 7 - Número de ocorrências de incêndio para os anos de 2005, 2006 e 2007 no Parque Municipal da Serra de São Domingos (Minas Gerias, Brasil) e seu entorno.

\begin{tabular}{|c|c|c|c|}
\hline Year & Occurrences & Causes & Occurrence places \\
\hline 2005 & 5 & $\begin{array}{l}\text { Two criminal } \\
\text { and three } \\
\text { unknown }\end{array}$ & $\begin{array}{l}\text { One in Fonte Leãozinho, } \\
\text { one in the Caldas da } \\
\text { Rainha Hotel ruins and } \\
\text { three non-specified }\end{array}$ \\
\hline 2006 & 6 & All unknown & $\begin{array}{l}\text { One in Asa Norte, one } \\
\text { in a cloverleaf leading } \\
\text { to the Christ statue and } \\
\text { four non-specified }\end{array}$ \\
\hline 2007 & 13 & $\begin{array}{l}\text { One criminal } \\
\text { and } 12 \\
\text { unknown }\end{array}$ & $\begin{array}{l}\text { One in a pasture area, } \\
\text { one in the free-flight } \\
\text { ramp, one in the road } \\
\text { leading to Pedra Balão, } \\
\text { one in the Caldas da } \\
\text { Rainha Hotel ruins, one } \\
\text { in a cloverleaf leading } \\
\text { to the Christ statue, two } \\
\text { near the Christ statue } \\
\text { and six non-specified }\end{array}$ \\
\hline
\end{tabular}

The resulting model, adapted from Chuvieco and Congalton (1989), calculates a structural fire index (SFI) for the Serra de São Domingos Municipal Park, as shown below:

$$
\mathrm{SFI}=0,35 i+0,30 u+0,15 d+0,10 a+0,10 e
$$

in which $i, u, d, a$ and $e$ represent, respectively, the influence of road system and buildings, land-use/cover, land slope, altitude and slope orientation. This formula generates values between one and five for each map pixel, which were reclassified in accordance with the coefficients (Table 8). 
Table 8 - Fire risk ranks and their coefficients for the Serra de São Domingos Municipal Park, Minas Gerais State, Brazil.

Tabela 8 - Classes de risco de incêndio e seus coeficientes para o Parque Municipal da Serra de São Domingos, Minas Gerais, Brasil.

\begin{tabular}{lc}
\hline Risk & Coefficient \\
\hline Low & $0.0-0.9$ \\
Moderate & $1.0-1.9$ \\
High & $2.0-2.9$ \\
Very high & $3.0-3.9$ \\
Extreme & $4.0-5.0$ \\
\hline
\end{tabular}

Source: Adapted from Oliveira et al. (2004).

\section{RESULTS AND DISCUSSION}

The fire risk map produced can be viewed in Figure 1. It shows that all five risk classes are present in the Park area, but they are not evenly distributed. The Moderate risk class alone, for instance, comprehends $61.77 \%$ of the Park's area, whereas only $0.93 \%$ fitted the Low risk class. Also, it can be observed a relatively clear pattern among the risk classes regarding their location within the Park, i. e., there are well-defined zones for each risk class.

This uneven distribution of the fire risk classes reinforces the importance of using multiple factors to compose the fire risk index. The native forest land-cover class, for example, is almost entirely under the Moderate risk class, even though it has been ranked as a low risk feature (Table 6). This "promotion" in the native forest fire risk class was due mainly to the influence of the land slope and the slope orientation, since most of the forest is located on the rugged part of the Park.

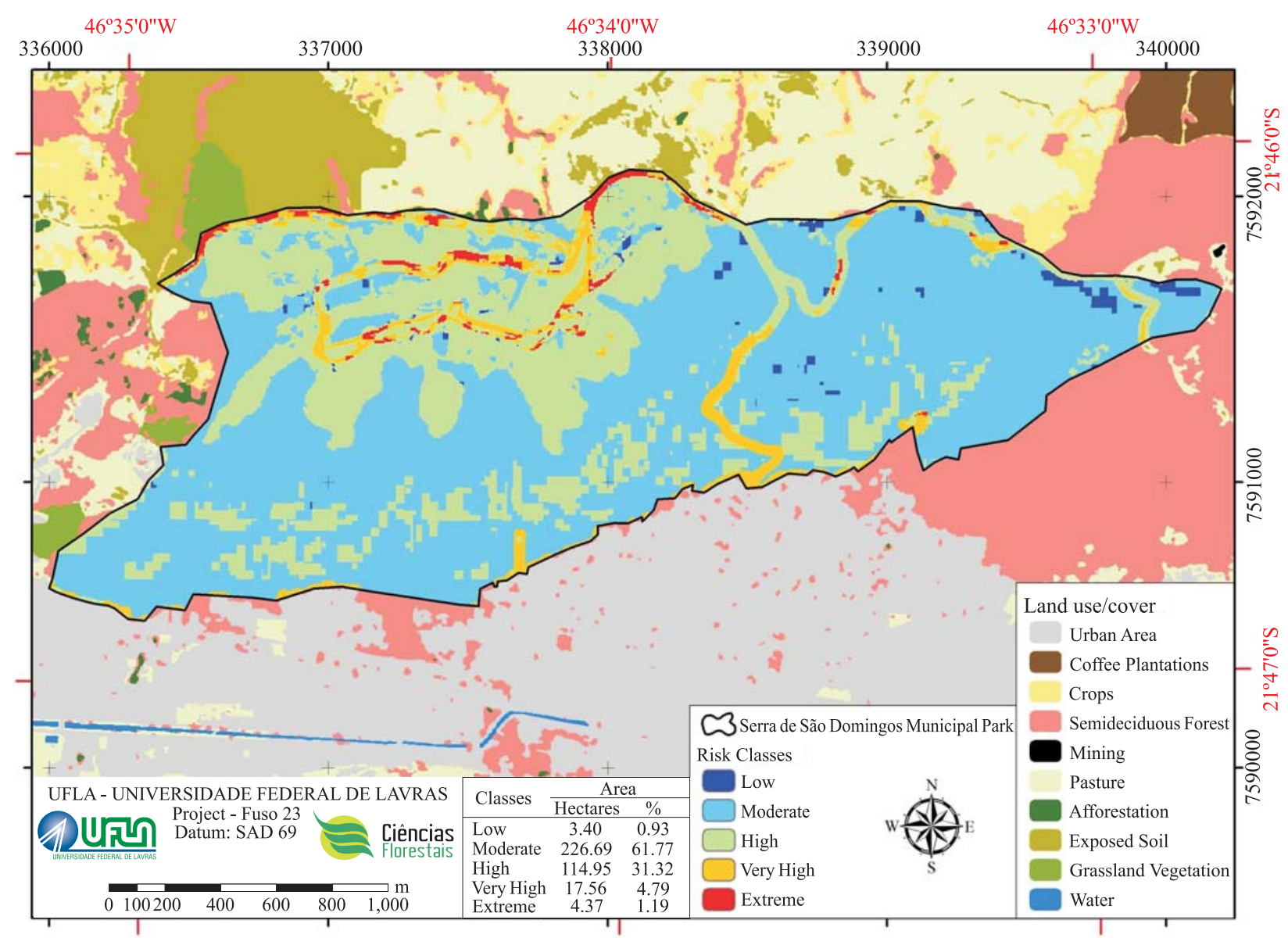

Figure 1 - Fire risk map for the Serra de São Domingos Municipal Park, Minas Gerais State, Brazil.

Figura 1 - Mapa de risco de incêndios para o Parque Municipal da Serra de São Domingos, Minas Gerais, Brasil. 
The SSDMP topography is conducive to the rapid spreading of fires, as most of the area has slopes superior to $20^{\circ}$ (Table 1 ). However, the negative effects of local topography are alleviated by two factors: the higher slopes are found in the lower part of the Park, where most of the rainforest is located and the flow of visitors is lower; and the roads are well-maintained, giving access to the upper part of the conservation unit, aiding firefighting and rescue operations.

Encompassing $31.32 \%$ of the Park area, the High risk class is mainly composed of the grassland vegetation that occupies the highest part of the Park and several scattered spots within the native forest areas (the Moderate risk zone). These spots represent some clearings as well as some steep and West-oriented slopes, drawing attention to the existence of vulnerable spots within the forest. Fire outbreaks at some of this spots will certainly menace the UC's most preserved feature, besides being areas of difficult access. Therefore, the fire prevention plan must include some steps to avoid great damages, such as the closing of some tourist trails that cross those areas and the setting of some water abstraction points close to them.

Many places that are under the road influence (an extreme risk factor) but are on less rugged terrain or above 1,400 $\mathrm{m}$ were also fit in the Moderate risk class. The remaining of the areas under the influence of roads and buildings fitted the Very High or the Extreme risk classes, comprehending 5.90\% of the Park.

No place beyond the influence of roads and buildings was fit in the Extreme risk class. Although corresponding to just $1.19 \%$ of the Park area, this class deserves keen attention, since it encompasses places with relatively high traffic and plantations (coffee and eucalypt). It is worth mentioning that commercial plantations within Natural Municipal Parks are forbidden by Brazilian Law (BRASIL, 2000). These features will probably be removed within some years from the implementation of the Park Management Plan.

From the fire risk map and the fire occurrence history it is possible to visualize that the SSDMP is naturally protected against fires. Coupled with the predominance of rainforest, Poços de Caldas climate also contributes to the low number of fire occurrences in the history of SSDMP. Other important factors are the CU's small size and location. Its monitoring is made directly from some highplaced spots in the city around the Park, and all firefighters and equipments are also mobilized from the city. However, this is not the ideal situation for the Park's safety.

Cerne, Lavras, v. 17, n. 1, p. 77-83, jan./mar. 2011
Firstly, the dependence entirely on the city for its protection might compromise SSDMP if a fire occurs while most equipments and firefighters are mobilized in another fire occurrence. It is worth mentioning that Poços de Caldas Fire Department serves other small cities close to Poços de Caldas. Secondly, the formation of a fire brigade for the Park would provide trained people not only to fight against fires and act in rescue operations but also to head fire prevention campaigns for tourists and townspeople.

The fire risk map also revealed the existence of a particularly vulnerable strip along the Northern border of the Park, which confronts with pasture, exposed soil and eucalypt plantations. There is only a dirt road separating these high-risk features from the Park. Since most of the fires in the SSDMP history have an anthropogenic cause (Table 7), a consciousness-raising campaign with the Park's neighbors might be even more productive than the establishment of firebreaks. The Brazilian Law also determines that, within some distant from any CU (the buffer zone), more environment-friendly agricultural practices must be adopted by farm owners (BRASIL, 2000).

In fact, the use of a structural fire index to produce a fire risk map has proved useful as a preliminary approach, identifying the most vulnerable zones within the Park. It will certainly aid the Management Plan team in the elaboration of the fire prevention plan. The risk map also revealed what is needed to increase its accuracy, if a better map is to be produced in a future Management Plan review: climate data and more detailed occurrence reports.

Since there is no climate station in Poços de Caldas and the occurrence reports are extremely simplistic, the adoption of an integrated fire risk at this point is unviable. However, if a climate station is settled in the Park and more precise information is included in the occurrence reports, such as GPS locations of fire focus and burned area extension, it might be possible to have such an index for, perhaps, the second review of the Management Plan, which is usually reviewed every five years. In this case, a map showing not only the most vulnerable areas but also the fire outbreaks most vulnerable periods might be producible with these relatively simple and available tools.

\section{CONCLUSIONS}

- The main fire risk factors at the Serra de São Domingos Municipal Park are the influence of roads and buildings since most fires at SSDMP start due to anthropogenic causes. 
- Most of the rainforest area fit the Low and the Moderate risk classes.

- Clearings and grasslands fit mainly the High risk class.

- The most vulnerable area of SSDMP is its Northern part, bordering pasture, crops and eucalypt fields.

- The structural fire index risk map is a valuable tool for performing a fire prevention plan in a small conservation unit with few climate and fire occurrence data available.

\section{ACKNOWLEDGEMENTS}

The authors thank the Poços de Caldas authorities and workers that provided assistance throughout the carrying out of this research: Corpo de Bombeiros, Guarda Verde, Guarda Municpal and Departamento de Proteção Ambiental. The fruitful comments from the anonymous revisers are also greatly acknowledged.

This work was financed by the Poços de Caldas City Hall in cooperation with Fundação de Desenvolvimento Científico e Cultural (FUNDECC).

\section{REFERENCES}

BRASIL. Lei n. 9.985, de 18 de julho de 2000. Regulamenta o art. 225, § $1^{\circ}$, incisos I, II, III e VII da Constituição Federal, institui o Sistema Nacional de Unidades de Conservação da Natureza e dá outras providências. Brasília: Congresso Nacional, 2000. 23 p.

CHUVIECO, E.; CONGALTON, R. G. Application of remote sensing and geographic information systems to forest fire hazard mapping. Remote Sensing of Environment, New York, v. 29, p. 147-159, 1989.

CHUVIECO, E. et al. Development of a framework for fire risk assessment using remote sensing and geographic information system technologies. Ecological Modelling, v. 221, p. 46-58, 2010.

DALCUMUNE, M. A. B.; SANTOS, A. R. Mapeamento de índice de risco de incêndio para a Região da Grande Vitória/ ES, utilizando imagens do satélite LANDSAT para o ano de 2002. In: SIMPÓSIO BRASILEIRO DE SENSORIAMENTO REMOTO, 12., 2005, Goiânia. Anais... Goiânia: INPE, 2005. p. $1485-1492$.
FERNANDES, M. R. et al. Poços de Caldas: caracterização de ecossistemas. Belo Horizonte: EMATER-MG, 2003. 56 p.

FERRAZ, S. F. B.; VETTORAZZI, C. A. Mapeamento de risco de incêndios florestais por meio de sistema de informações geográficas (SIG). Scientia Forestalis, Piracicaba, v. 53, p. 39-48, 1998.

FREIRE, S.; CARRÃO, H.; CAETANO, M. R. Produção de cartografia de risco de incêndio florestal com recurso a imagens de satélite e dados auxiliares. 2002. Available in: < http://www.igeo.pt/gdr/pdf/Freire2002.pdf>. Access in: 8 July 2010.

HERNANDEZ-LEAL, P. A.; ARBELO, M.; GONZALEZCALVO, A. Fire risk assessment using satellite data.

Advances in Space Research, v. 37, p. 741-746, 2006.

NÚÑEZ-REGUEIRA, L.; PROUPÍN-CASTIÑEIRAS, J.; RODRÍGUEZ-AÑÓN, J. A. Design of risk index maps as a tool to prevent forest fires in the hill-side zone of Galicia (NW Spain). Bioresource Technology, v. 73, p. 123-131, 2000.

OLIVEIRA, D. dos S. de et al. Zoneamento de risco de incêndios florestais para o estado do Paraná. Floresta, Curitiba, v. 34, n. 2, p. 217-221, 2004.

RIBEIRO, L.; KOPROSKI, L. P.; STOLLE, L.; LINGNAU, C.; SOARES, R. V.; BATISTA, A. C. Zoneamento de riscos de incêndios florestais para a fazenda experimental do Canguiri, Pinhais (PR). Floresta, Curitiba, v. 38, n. 3, 2008.

SALAS, J.; CHUVIECO, E. Geographic information systems for wildland fire risk mapping. Wildfire, v. 3, n. 2, p. 7-13, 1994.

SANT’ANNA, C. de M.; PEREIRA, J. A. A.; BORÉM, R. A. T. Prevenção e combate a incêndios florestais. Lavras: UFLA/FAEPE, 2001. 88 p.

SOARES, R. V. Incêndios florestais: controle e uso do fogo. Curitiba: FUPEF, 1985. 213 p.

SOARES, R. V.; BATISTA, A. C. Incêndios florestais: controle, efeitos e uso do fogo. Curitiba, 2007. 264 p.

SOUZA, M. P. et al. Zoneamento ambiental do município de Poços de Caldas (MG): subsídios ao planejamento territorial. Poços de Caldas: EMATER-MG, 2007. 41 p. 